\title{
Phosphate transporters, PnPht1;1 and PnPht 1;2 from Panax notoginseng enhance phosphate and arsenate acquisition
}

Guan-Hua Cao ${ }^{1,2}$, Ze-Dong Li ${ }^{1}$, Xi-Fu Wang ${ }^{1}$, Xue Zhang ${ }^{1}$, Rong-Hua Zhao ${ }^{1}$, Wen Gu', Di Chen ${ }^{1}$, Jie Yu ${ }^{1 *}$ and Sen $\mathrm{He}^{1 *}$ (D)

\begin{abstract}
Background: Panax notoginseng is a medicinally important Chinese herb with a long history of cultivation and clinical application. The planting area is mainly distributed in Wenshan Prefecture, where the quality and safety of $P$. notoginseng have been threatened by high concentration of arsenic (As) from the soil. The roles of phosphate (Pi) transporters involved in $\mathrm{Pi}$ acquisition and arsenate (AsV) tolerance were still unclear in this species.

Results: In this study, two open reading frames (ORFs) of PnPht1;1 and PnPht1;2 separated from P. notoginseng were cloned based on RNA-seq, which encoded 527 and 541 amino acids, respectively. The results of relative expression levels showed that both genes responded to the Pi deficiency or As exposure, and were highly upregulated. Heterologous expression in Saccharomyces cerevisiae MB192 revealed that PnPht1;1 and PnPht1;2 performed optimally in complementing the yeast Pi-transport defect, particularly in PnPht1;2. Cells expressing PnPht1;2 had a stronger AsV tolerance than PnPht 1;1-expressing cells, and accumulated less As in cells under a high-Pi concentration. Combining with the result of plasma membrane localization, these data confirmed that transporters PnPht 1;1 and PnPht1;2 were putative high-affinity $\mathrm{H}^{+} / \mathrm{H}_{2} \mathrm{PO}_{4}{ }^{-}$symporters, mediating the uptake of $\mathrm{Pi}$ and $\mathrm{AsV}$.

Conclusion: $P n P h t 1 ; 1$ and PnPht1;2 encoded functional plasma membrane-localized transporter proteins that mediated a putative high-affinity $\mathrm{Pi} / \mathrm{H}^{+}$symport activity. Expression of $\mathrm{PnPht1;1}$ or PnPht1;2 in mutant strains could enhance the uptake of $\mathrm{Pi}$ and $\mathrm{AsV}$, that is probably responsible for the As accumulation in the roots of $P$. notoginseng.
\end{abstract}

Keywords: Phosphate transporter, Arsenate exposure, Phosphate deficiency, Panax notoginseng

\section{Background}

Panax notoginseng (Burk.) F.H. Chen is a rare and wellknown perennial herb, of which the main medicinal part is radix, and has been used for 600 years in clinical treatment with clearly medicinal actions of dissipating blood stasis, arresting bleeding, blood-activating, and inflammationdiminished, thereby promoting the elimination of swelling and relieving pain [1-3]. Wenshan Autonomous Prefecture

\footnotetext{
*Correspondence: cz.yujie@gmail.com; senhe2019@outlook.com ${ }^{1}$ College of Traditional Chinese Medicine, Yunnan University of Chinese Medicine, Kunming, Yunnan, China

Full list of author information is available at the end of the article
}

in Yunnan Province is famous for the cultivation of P. notoginseng, where the arsenic (As) concentration in background soil is very high, and partially caused by mining activities and the use of As-containing pesticides [2, 4]. Previous studies found that almost half of cultivated fields had a crisis of excessive As in the Wenshan area, of which 21 fields were analyzed in total [1]. Thus, As accumulation in P. notoginseng has a closed link with background value in soil. Investigations indicated that As content in the radix, stems, and flowers occasionally exceeded the threshold value $(2.0 \mathrm{mg} / \mathrm{kg}$, As standard of China Green Trade

(c) The Author(s). 2020 Open Access This article is licensed under a Creative Commons Attribution 4.0 International License, which permits use, sharing, adaptation, distribution and reproduction in any medium or format, as long as you give appropriate credit to the original author(s) and the source, provide a link to the Creative Commons licence, and indicate if changes were made. The images or other third party material in this article are included in the article's Creative Commons licence, unless indicated otherwise in a credit line to the material. If material is not included in the article's Creative Commons licence and your intended use is not permitted by statutory regulation or exceeds the permitted use, you will need to obtain permission directly from the copyright holder. To view a copy of this licence, visit http://creativecommons.org/licenses/by/4.0/ The Creative Commons Public Domain Dedication waiver (http://creativecommons.org/publicdomain/zero/1.0/) applies to the data made available in this article, unless otherwise stated in a credit line to the data. 
Standards of Importing and Exporting Medicinal, China). The over-standard rate was up to $56 \%$ in 31 samples [5-7].

As a highly toxic material, Arsenic is very dangerous to human health, of which the toxic effect would be magnified through bioconcentration [8]. Phosphorus (P) is an essential macronutrient that plays important roles in the biosynthesis of membranes, phospholipids and nucleic acids, energy transfer reactions and signal transduction [9]. Phosphate (Pi), e.g., $\mathrm{H}_{2} \mathrm{PO}_{4}{ }^{-}$, the main form of inorganic $\mathrm{P}$ in soil, is taken up by plants through Pi transporters, which are usually driven by a proton gradient generated, that is, plasma membrane $\mathrm{H}^{+}$-ATPases [10-12].

Due to the similar electrochemical characteristics of $\mathrm{P}$ and $\mathrm{AsV}$, studies found that Pi transporters were not only employed to mediate both Pi uptake and translocation in plants but also the carrier of AsV, which is a primary plantavailable form of As in soil [12, 13]. Numerous Pi transporters were involved in the uptake of $\mathrm{Pi}$ and As, e.g., PvPht1;3 in Pteris vittata [13], Pht1;9 in Arabidopsis thaliana [9], OsPht1;8, OsPT1, OsPT2, OsPT4, and OsPT8 in Oryza sativa [14-17], HvPht1;8 in Hordeum vulgare [18], PHT1;3, PHT1;4, and PHT1;12 in Salix spp. [19]. Pi transporters have three subfamilies, including Pht1, Pht2, and $\mathrm{PHO}$, in which Pht1 is usually induced by micromolar $\mathrm{Km}$ values, belonging to the high-affinity Pi transporter, and Pht2 is constitutively expressed with millimolar $\mathrm{Km}$, and is known as the low-affinity Pi transporter [20-23]. Suppression of AsV uptake is a common mechanism via supplementation with sufficient $\mathrm{Pi}$ due to the competition uptake between $\mathrm{AsV}$ and $\mathrm{Pi}[13,24]$. Evidence suggested that $\mathrm{AsV}$ uptake was repressed by an increase in the Pi concentration, primarily due to the decline of Pht1's roles [25, 26]. However, the alleviation of AsV uptake may be affected by upregulated expression of certain Pht1 genes [18, 27, 28], with the transporters exhibiting low affinity for $\mathrm{AsV}[13,29]$.

Currently, little is known about the roles of Pi transporters of $P$. notoginseng in the uptake of $\mathrm{Pi}$ and $\mathrm{AsV}$ under the stresses of Pi deficiency or As exposure. In this study, we focused on the identification of two Pi transporterencoding genes and their roles in enhancing $\mathrm{Pi}$ and $\mathrm{AsV}$ acquisition, both of which, PnPht1;1 and PnPht1;2 were separated from the fibrous roots of $P$. notoginseng, and responded positively to the stresses of Pi deficiency or As exposure. In this paper, an ideal approach to uncovering the mechanism of Pi/AsV uptake of PnPht1;1 and PnPht1;2 is to employ mutant yeasts that significantly alter this uptake with Pi-AsV interplay. Expression of PnPht1;1 and $P n P h t 1 ; 2$ decreased the As uptake and accumulation in the mutant cell, as Pi addition was sufficient. In addition, the results of subcellular localization would help to elucidate the roles of of PnPht1;1 and PnPht1;2 in Pi/AsV uptake. Our findings will be helpful for achieving the repression of As accumulation in $P$. notoginseng and decreasing the health risk associated with As.

\section{Results}

PnPht 1;1 and PnPht1;2 encode two Pht1 Pi transporters The ORF lengths of PnPht1;1 and PnPht1;2 cDNA are 1581 and $1623 \mathrm{bp}$, respectively. The predicted translation products are 527 and 541 amino acids for PnPht1;1 and PnPht1;2 with calculated molecular masses and isoelectric points of $57.53 \mathrm{kDa} / 9.08$ and $59.43 \mathrm{kDa} / 9.43$, respectively. PnPht1;1 and PnPht1;2 Pi transporters are similar, consisting of 11 transmembrane domains and a Pht1 signature sequence (GGDYPLSATIxSE) [30] in the red-line box, as shown in Fig. 1. A high homology of peptide sequences was shown among PnPht1;1, PnPht1;2 and known plant Pht1 proteins, 76.2 and $79.3 \%$ with LsPht1 (GenBank accession number, KY305670.1), 69.0 and $68.8 \%$ with OsPht1 (AY332471.1), and 69.7 and 70.3\% with SoPht1 (XM 022007438.1) (Fig. 1). A phylogenetic analysis confirmed that both $P_{n P h t 1 ; 1}$ and $P_{n P h t 1 ; 2}$ belonged to the Pht1 subfamily and were very closely related to $N$. benthamiana and P. vittata homologues NtPht1;1 and PvPht1;1, particularly with the former (Fig. 2). Additionally, the transient expression of PnPht1;1 and PnPht1;2 in N. benthamiana leaves clearly indicated that both of them were localized to the plasma membrane (Fig. 3), similar to other Pht1 genes, e.g., PvPht1;2 and PvPht1;3 in P. vittata [13].

\section{PnPht1;1 and PnPht1;2 gene expression in the roots of $P$. notoginseng under Pi deficiency and As exposure}

An obvious phenomenon was uncovered: both PnPht1;1 and $P n P h t 1 ; 2$ positively responded to the Pi deficiency or As exposure and were highly upregulated (Fig. 4). Actually, the upregulations of $P n P h t 1 ; 1$ and $P n P h t 1 ; 2$ were higher under the stress of Pi deficiency, rather than As exposure, presenting a significantly difference of PnPht1;2 under a low-Pi treatment with or without As, e.g., PnPht1; 1: 28.4-fold increase with IPnAs, 25.6-fold increase with IPhAs, 8.5-fold increase with mPhAs, and 10.8-fold increase with hPhAs; PnPht1;2: 105.6-fold increase with IPnAs, 67.2-fold increase with IPhAs, 5.4-fold increase with $\mathrm{mPhAs}$, and 11.8-fold increase with hPhAs. Note that supplementation with AsV could decrease the expression level in IP groups (IPnAs and IPhAs), e.g., PnPht1;1: 28.4fold increase with IPnAs and 25.6-fold increase with of lPhAs; PnPht1;2: 105.6-fold increase with $1 \mathrm{PnAs}$ and 67.2fold increase with $1 \mathrm{PhAs}$. Interestingly, compared with low phosphate (IP) treatment, the expression levels of PnPht1; 1 and $P n P h t 1 ; 2$ sharply decreased under supplementation with sufficient $\mathrm{Pi}(0.7 \mathrm{mM}$ and $1.4 \mathrm{mM})$.

\section{Complementation tests in yeast MB192}

Heterologous expression of PnPht1;1 and PnPht1;2 in mutant yeast MB192 complemented the defects in the highaffinity Pi transporter gene and enabled the yeast to survive at low concentrations of $\mathrm{Pi}(0.002 \mathrm{mM}$ and $0.02 \mathrm{mM})$ by enhancing Pi uptake (Fig. 5). The $\mathrm{OD}_{600}$ of strains 


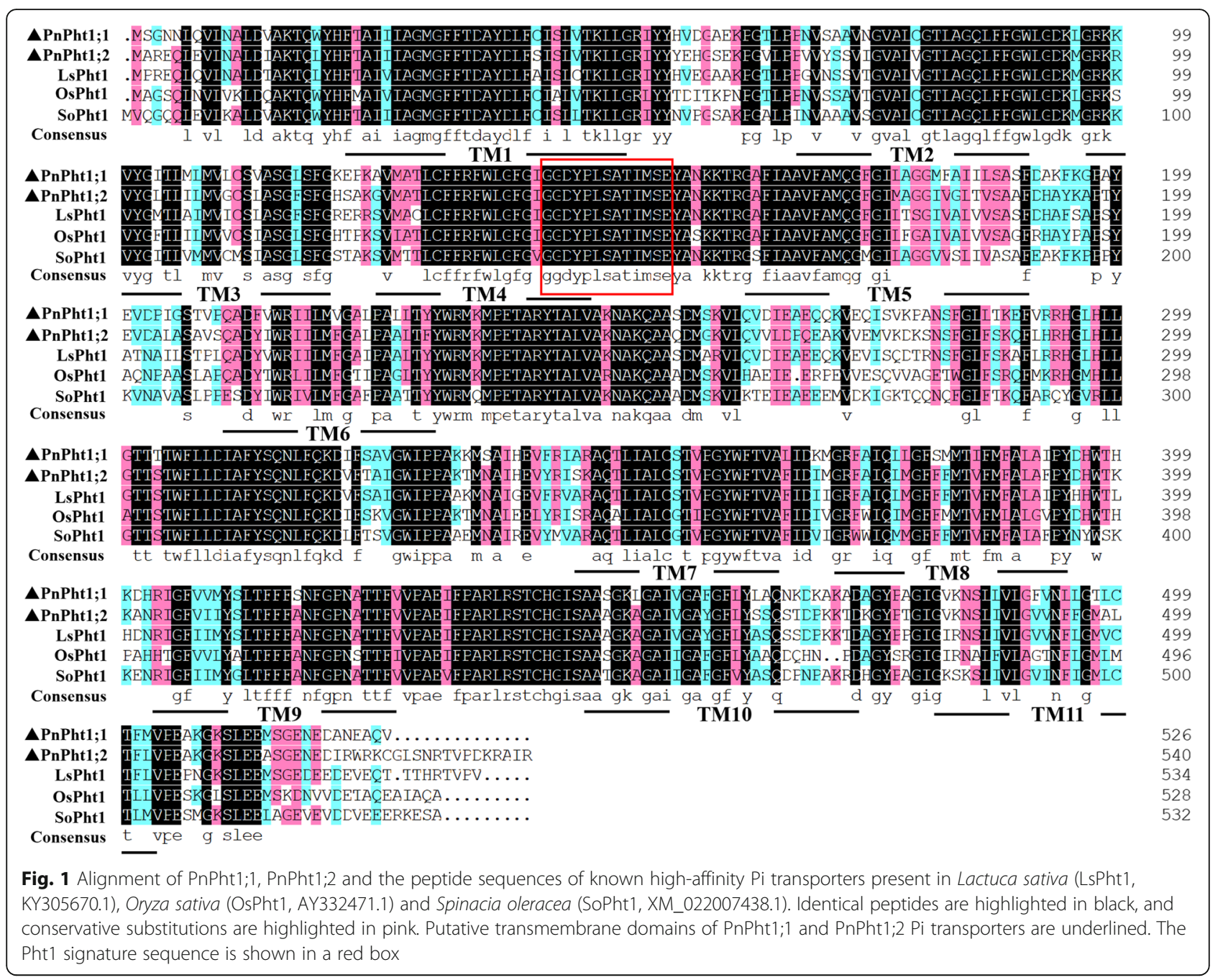

MB192-PnPht1;1 and MB192-PnPht1;2 were remarkably higher than those of MB192 and MB192-YEplac112 and were near those of WT type (Fig. 5a). Both logarithmic phases of cells expressing PnPht1;1 or PnPht1;2 were from 10th $h$ to 25th h (Fig. 5a). Clearly, the color of medium culturing MB192-PnPht1;1 or MB192-PnPht1;2 was close to WT, in yellow at $0.002 \mathrm{mM}, 0.02 \mathrm{mM}$, and $0.06 \mathrm{mM} \mathrm{Pi}$ concentration, while MB192 and MB192-YEplac112 were purple or faint yellow (Fig. 5b). The color changed with $\mathrm{pH}$, which was closely related to acid phosphatase activity (ACP). As shown in Fig. 5c, the ACPs of MB192-PnPht1;1 and MB192-PnPht1;2 were higher than those of MB192YEplac112 and MB192 and presented significant differences. The optimal $\mathrm{pH}$ value for the growth of yeasts was 6 , and followed by 5 (Fig. $5 \mathrm{~d}$ ). In addition, the $\mathrm{OD}_{600}$ of MB192-PnPht1;1 and MB192-PnPht1;2 were distinctly suppressed by supplements with respiratory inhibitors, carbonyl cyanide $m$-chlorophenylhydrazone (CCCP), or 2 , 4-dinitrophenol (2,4-DNP) (Fig. 4e). Thus, these results confirmed the conclusion that Pi transporters, PnPht1;1 and PnPht1;2 are putative high-affinity $\mathrm{H}^{+} / \mathrm{H}_{2} \mathrm{PO}_{4}{ }^{-}$symporters, mediating Pi uptake.

In addition, growth rate coefficients were evaluated via exponential regression based on the logarithmic growth phase. Representative assays are shown in Fig. 6a-c, and the means of a number of independently obtained growth rate coefficients for each transporter $(n=4)$ are shown in Fig. 6d. Under a low Pi concentration $(20 \mu \mathrm{M})$, the growth rate coefficient of MB192-YEplac112 was relatively low (0.0984), while the cells harboring PnPht1; 1 or PnPht1;2 had a higher coefficient $(0.1594,0.163)$. These results revealed that both PnPht1;1 and PnPht1;2 Pi transporters performed optimally in complementing the yeast Pi-transport defect, particularly in PnPht1;2.

\section{Yeast cells expressing PnPht1;1 and PnPht1;2 improve As tolerance}

Current evidence show that the phosphate transport system is the main pathway for AsV uptake. However, AsV uptake is competitively inhibited by sufficient Pi [28]. As 


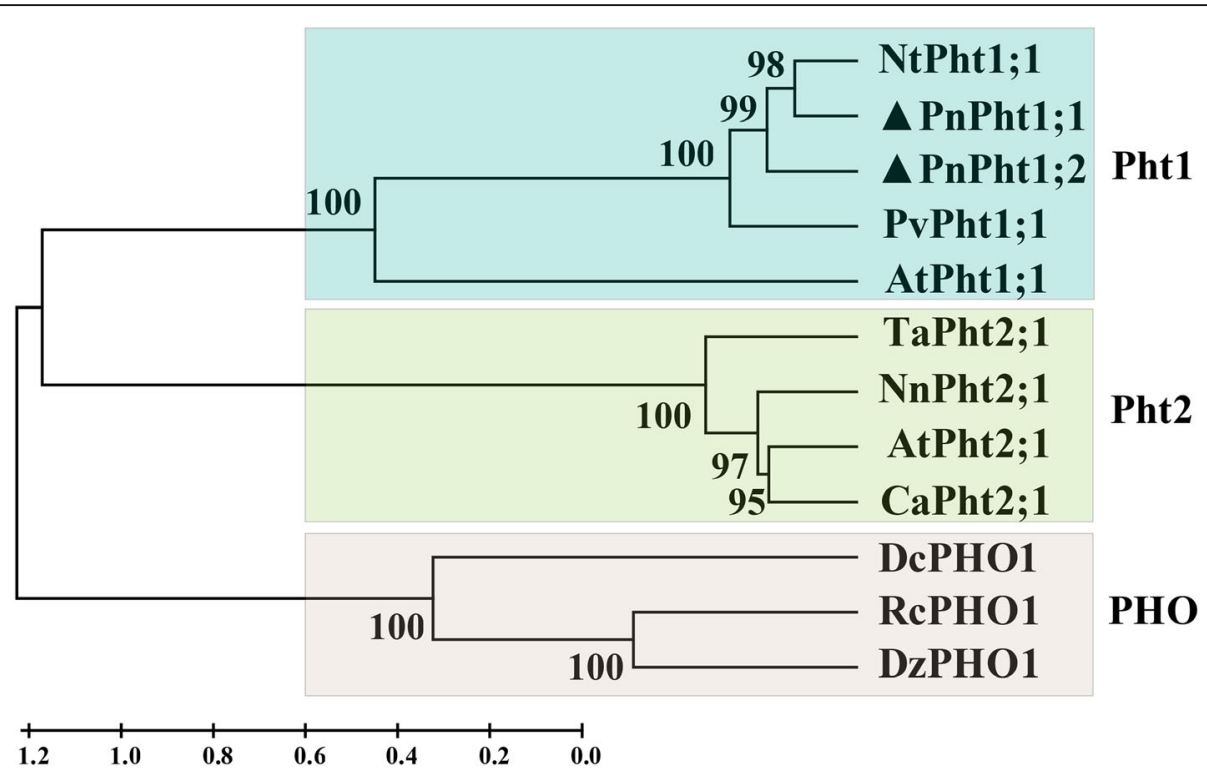

Fig. 2 Phylogenetic relationships among PnPht1;1, PnPht1;2, and other plant Pi transporters. PvPht1;1 (KM192135.1) from Pteris vittata; NtPht1;1 (AF156696.1) from Nicotiana tabacum; AtPht1;1 (NM_106293.4) and AtPht2;1 (NM_113565.3) from Arabidopsis thaliana; NnPht2;1 (XM_010250335.2) from Nelumbo nucifera; TaPht2;1 (AY293827.1) from Triticum aestivum; CaPht2;1 (XM_004509617.3) from Cicer arietinum; DcPHO1 (XM_017360779.1) from Daucus carota; RcPHO1 (XM_015716472.2) from Ricinus communis; DzPHO1 (XM_022904580.1) from Durio zibethinus. The bootstrap value was calculated with 1000 replications

shown in Fig. 7, the growth of transgenic yeasts and mutant strain that was used exhibited similar trends in $50 \mu \mathrm{M}$ Pi medium, indicating that transporters PnPht1;1 and PnPht1;2 had the same uptake characteristics for Pi and AsV. The growth rate coefficient of cells expressing
PnPht1;1 or PnPht1;2 under $50 \mu \mathrm{M}$ Pi were higher than the values determined in low-Pi $(25 \mu \mathrm{M})$ medium described in the previous section. Under $80 \mu \mathrm{M}$ AsV treatment, the growth rate coefficients of MB192-YEplac112, MB192-PnPht1;1, and MB192-PnPht1;2, were 0.0562,

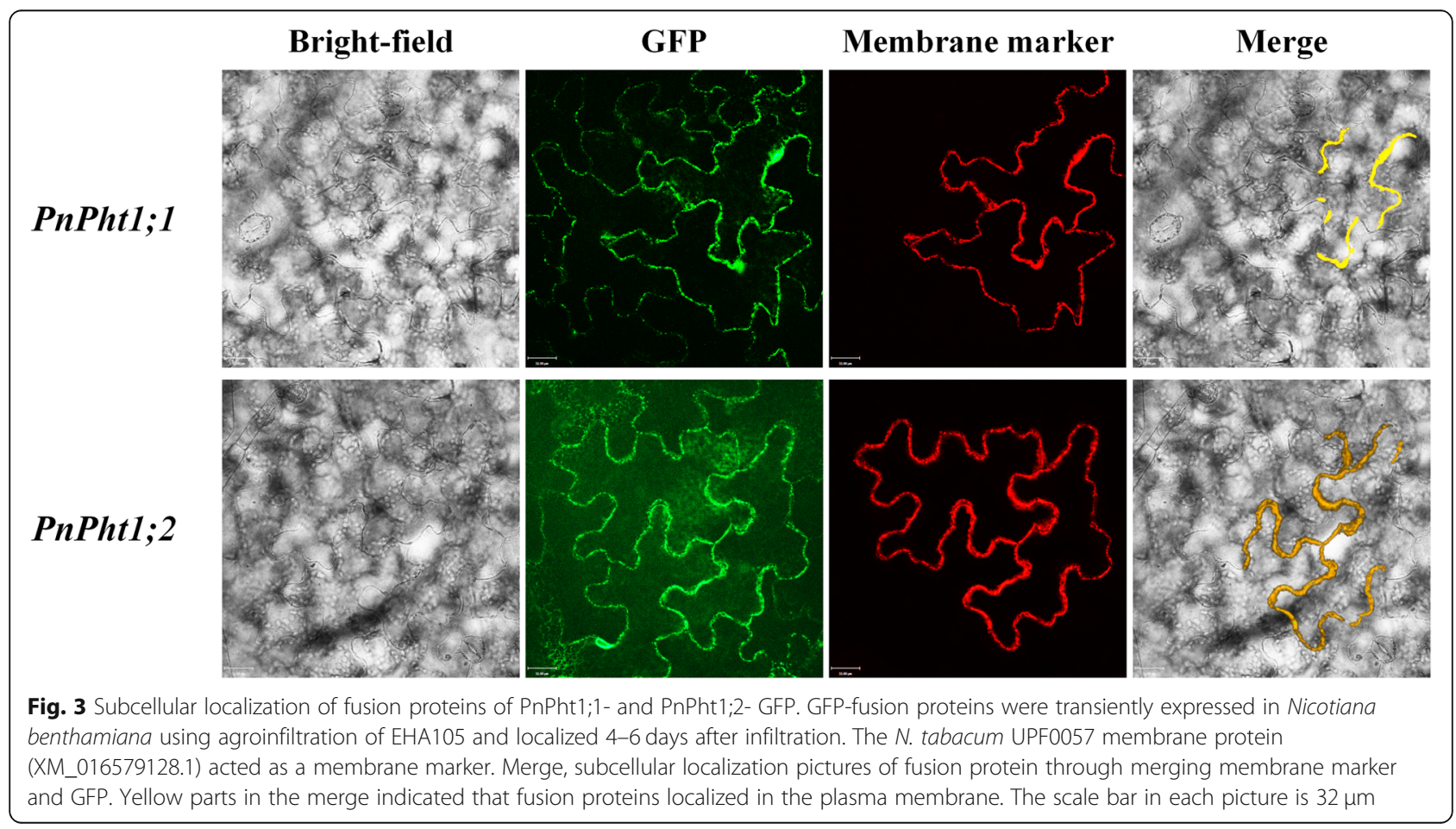



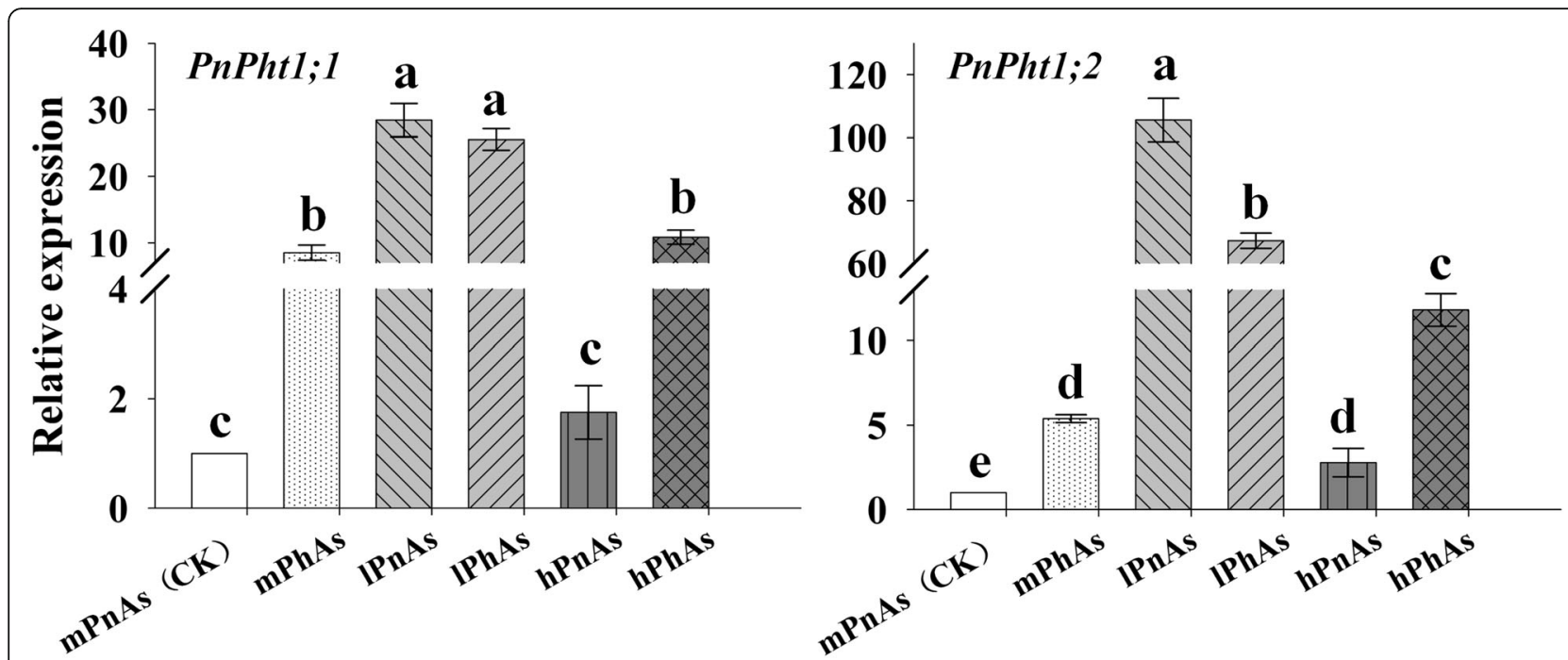

Fig. 4 Relative expression levels of $P n P h t 1 ; 1$ and $P n P h t 1 ; 2$ in the roots of Panax notoginseng with different Pi supplements under AsV stress. Oneyear-old $P$. notoginseng plants in good condition were treated with different phosphate concentrations $\left(\left(\mathrm{KH}_{2} \mathrm{PO}_{4}\right), 0.07 \mathrm{mM}(\mathrm{IP}), 0.7 \mathrm{mM}(\mathrm{mP})\right.$, and $1.4 \mathrm{mM}(\mathrm{hP}))$ and were supplemented with or without $0.20 \mathrm{mM} \mathrm{AsV}\left(\mathrm{Na}_{3} \mathrm{AsO}_{4}\right)$. mPnAs $(0.7 \mathrm{mM}$ Pi and non-AsV) was used as a control. Different lowercase letters represent a difference of $P n P h t 1 ; 1$ or $P n P h t 1 ; 2$ among different treatments, $P \leq 0.05$. Error bars indicate mean values \pm SD, $(n=4)$

0.0892, and 0.1036, respectively (Fig. 7a, b, c). The As tolerance for each transgenic line was assessed by calculating the percentage of growth under As exposure relative to growth in the absence of As. The results revealed that the As tolerance of MB192-PnPht1;2 was significantly stronger than that of MB192-PnPht1;1 and MB192-YEplac112. Although As tolerance of MB192PnPht1;1 was also larger than MB192-YEplac112, the difference was non-obvious (Fig. 7d).

As shown in Fig. 8a, the OD $_{600}$ of WT, MB192-PnPht1;1 and MB192-PnPht1;2 significantly increased with the elevation of Pi concentration from $20 \mu \mathrm{M}$ to $100 \mu \mathrm{M}$, suggesting that high Pi concentration relieved the stress of AsV. However, the change of $\mathrm{OD}_{600}$ of mutant strains were not obvious. Additionally, $\mathrm{OD}_{600}$ of PnPht1;2-expressing cells was a little larger than MB192-PnPht1;1 without a significant difference under the same treatments containing $80 \mu \mathrm{M} \mathrm{AsV}$. The phenomenon revealed that Pi addition may improve the probability, that Pi transporters assimilate Pi under the competition of AsV. Under a high level of Pi concentration, PnPht1;1 and PnPht1;2 preferred to combine Pi. The discovery was reinforced by the As accumulation in cells of WT, MB192-PnPht1;1 and MB192-PnPht1;2, which decreased with the addition of high Pi concentration (Fig. 8b). The decreased As of MB192-PnPht1;2 presented a significant difference from $20 \mu \mathrm{M}$ to $100 \mu \mathrm{M}$ Pi concentration, as well as WT. The As concentration of MB192-PnPht1;1 or MB192-PnPht1;2 was significantly less than WT under 20 or $100 \mu \mathrm{M}$ Pi concentration, but significantly higher than mutant strains of MB192 and MB192-YEplace112 under $20 \mu \mathrm{M} \mathrm{Pi}$ (Fig. 8b). It is worth mentioning that it's still a significant difference between the As concentration of
MB192-PnPht1;1 and mutant strains under $100 \mu \mathrm{M}$ Pi. For MB192-PnPht1;1 and MB192-PnPht1;2, the difference was significant under $100 \mu \mathrm{M}$ Pi concentration. MB192-PnPht1; 1 accumulated over 2.3-fold more arsenic than cells expressing PnPht1;2, suggesting that PnPht1;1 was likely to combine AsV compared to PnPht1;2. Combined with the results of As tolerance in Fig. $7 d$, it is concluded that the transporters PnPht1;1 and PnPht1;2 had different capacities of assimilating As, and the PnPht1;2-expressing cells had a stronger As tolerance. In addition, a high Pi concentration could alleviate As stress.

\section{Discussion}

P. notoginseng is an important Chinese medicinal plant, of which the rhizome are main medicinal portions containing active substances, e.g. notoginsenoside. However, the quality of $P$. notoginseng has been threatened by high concentration of As in primary producing areas [1]. The results of cultivation showed that As content in the roots of $P$. notoginseng gradually increased with elevated AsV concentration but significantly decreased with a high level of $\mathrm{Pi}$ concentration under the high-As treatment (Figure S1). In the process, Pi transporters play a vital role in uptake and translocation [31, 32].

Herein, we identified two Pi transporter-encoding genes, $P n P h t 1 ; 1$ and PnPht1;2, from the fibrous roots of P. notoginseng under the treatments of Pi deficiency and AsV exposure. According to the bioinformatics and phylogenetic tree, both PnPht1;1 and PnPht1;2 belonged to subfamily Pht1 with the signature sequence "GGDYPLSATIxSE" and 11 transmembrane domains (Figs. 1 and 2), which is the primary pathway of Pi uptake and translocation [13]. 


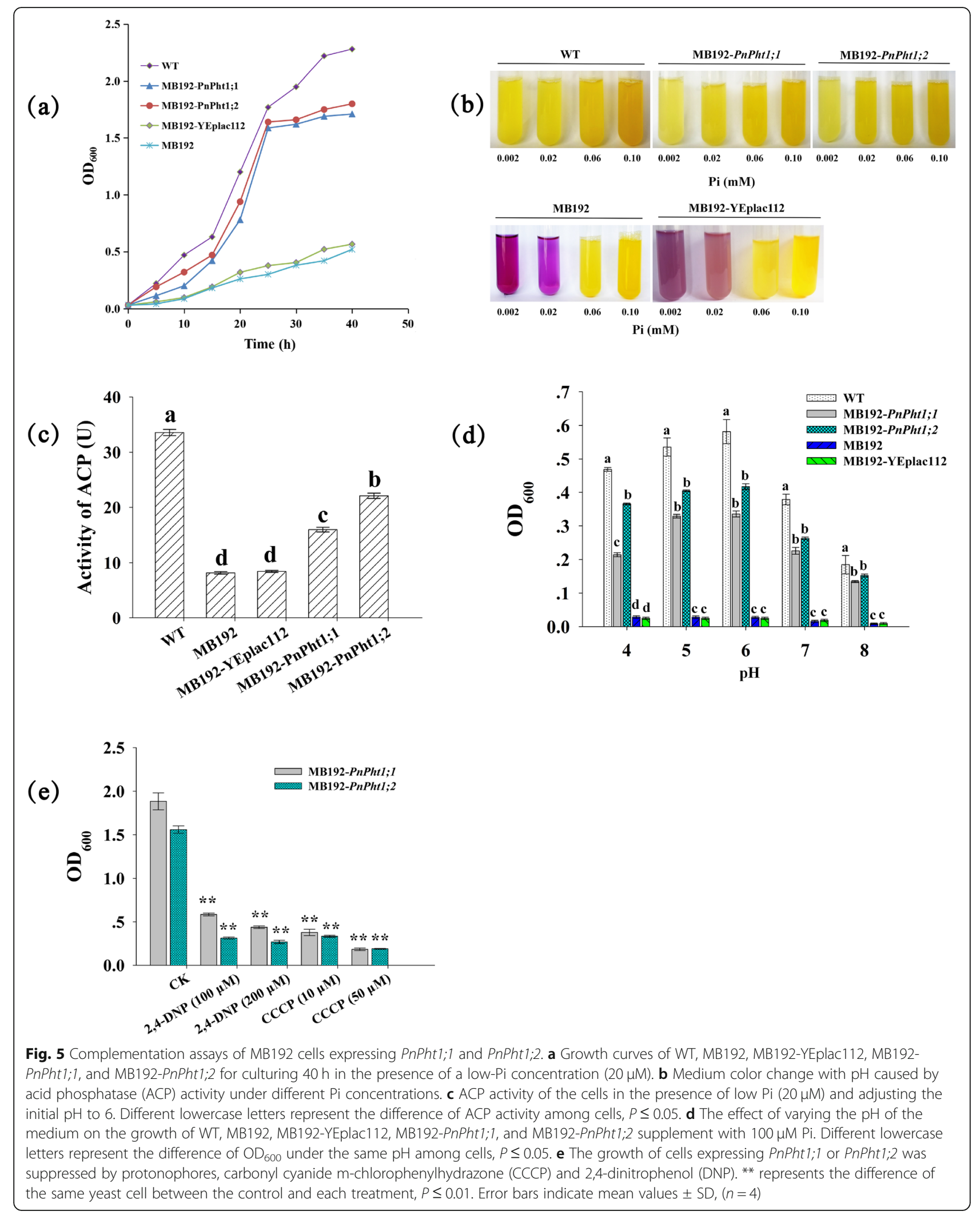



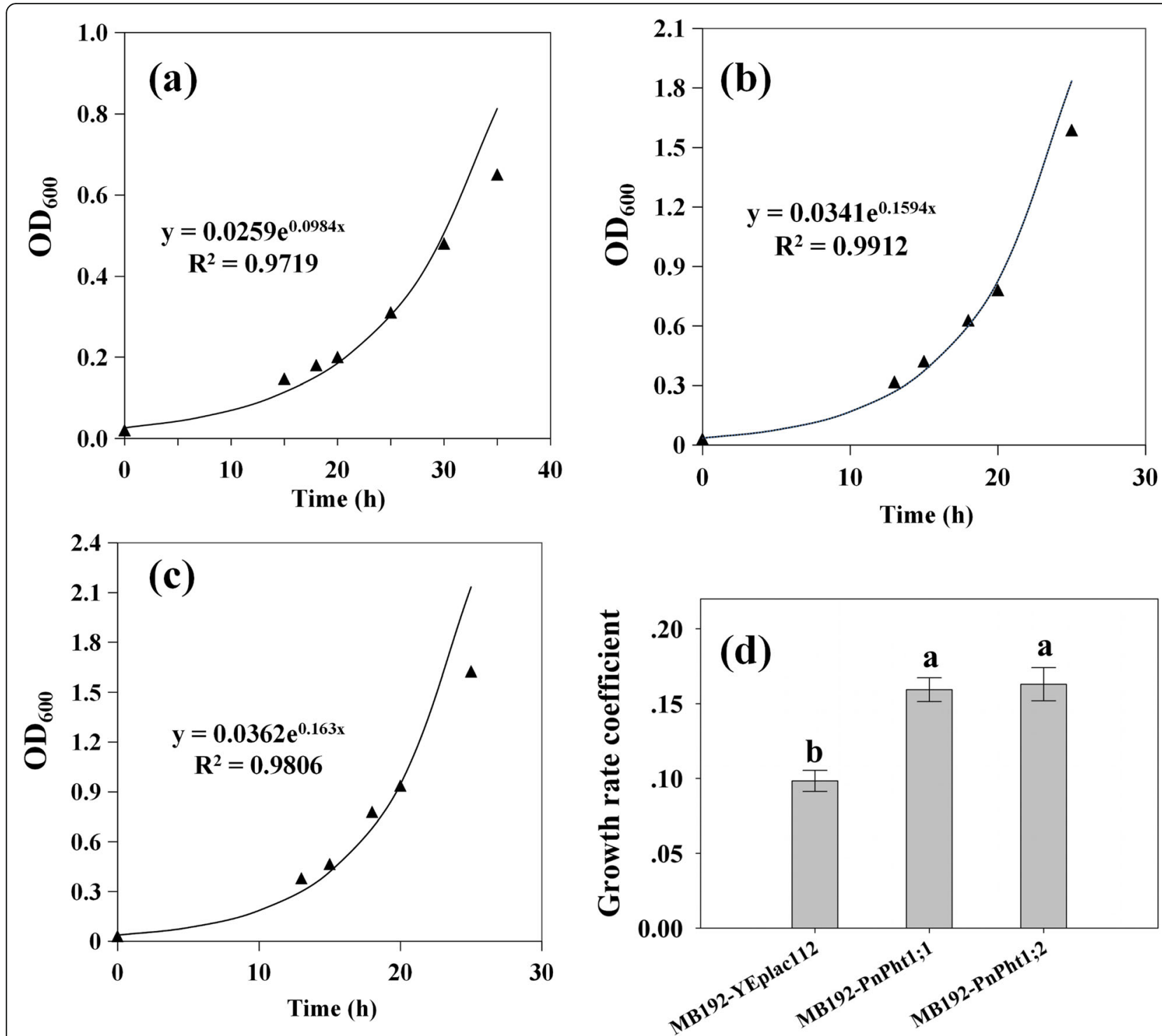

Fig. 6 Growth rates of cells expressing PnPht1;1 or PnPht1;2 supplement with $20 \mu \mathrm{M}$ Pi. Measurements of $\mathrm{OD}_{600}$ during logarithmic growth were used to generate exponential trend lines $\left(y(t)=a \times e^{k t}\right)$, where $k$ is the growth rate coefficient. $\mathbf{a}$ Growth rates of cells expressing vector. $\mathbf{b}$ Growth rates of cells expressing PnPht1;1. c Growth rates of cells expressing PnPht1;2. d Growth rate coefficient. Different lowercase letters represent the difference of growth rate coefficient among cells, $P \leq 0.05$. Error bars indicate mean values $\pm S D,(n=4)$

Further evidence suggested that the Pi transporter was not only responsible for $\mathrm{Pi}$ uptake but also transport congeners of $P$, e.g., As $[16,27]$. This finding suggests a competitive relationship of substrates between $\mathrm{Pi}$ and AsV [17, 33, 34]. However, the affinity of Pi or As with the Pi transporter depends on the characteristics of the Pi transporters, the concentration, the duration or chemical speciation of $\mathrm{Pi}$ and As, and the tissue of plants [19, 26, 35-37]. In this study, qPCR results showed that upregulation of PnPht1;1 and PnPht1;2 expression is induced via either Pi deficiency or AsV exposure. In contrast, the responses of $P n P h t 1 ; 1$ and $P n P h t 1 ; 2$ to Pi deficiency are more positive than $\mathrm{AsV}$, of which the expression levels were increased by as much as 30- and 100-fold, respectively, suggesting that PnPht1;1 and PnPht1;2 would be high-affinity $\mathrm{Pi}$ transporters. Interestingly, an increasing concentration of AsV lowered the expression levels of PnPht1;1 and PnPht1;2 in the low-Pi treatment group (IPnAs and 1PhAs), especially for PnPht1;2 (Fig. 4). Increasing evidence have illuminated the phenomenon that numerous Pht1 genes could significantly respond to the induction of Pi deficiency or As exposure, e.g., upregulation of OsPT1, OsPT2, OsPT4 and OsPT8 in O. sativa, CmPT1 in Chrysanthemum morifolium, and PvPht1;3 in P. vittata under Pi deficiency or As exposure [13, 38, 39], and downregulation of $P v P h t 1 ; 1$ in P. vittata under As 

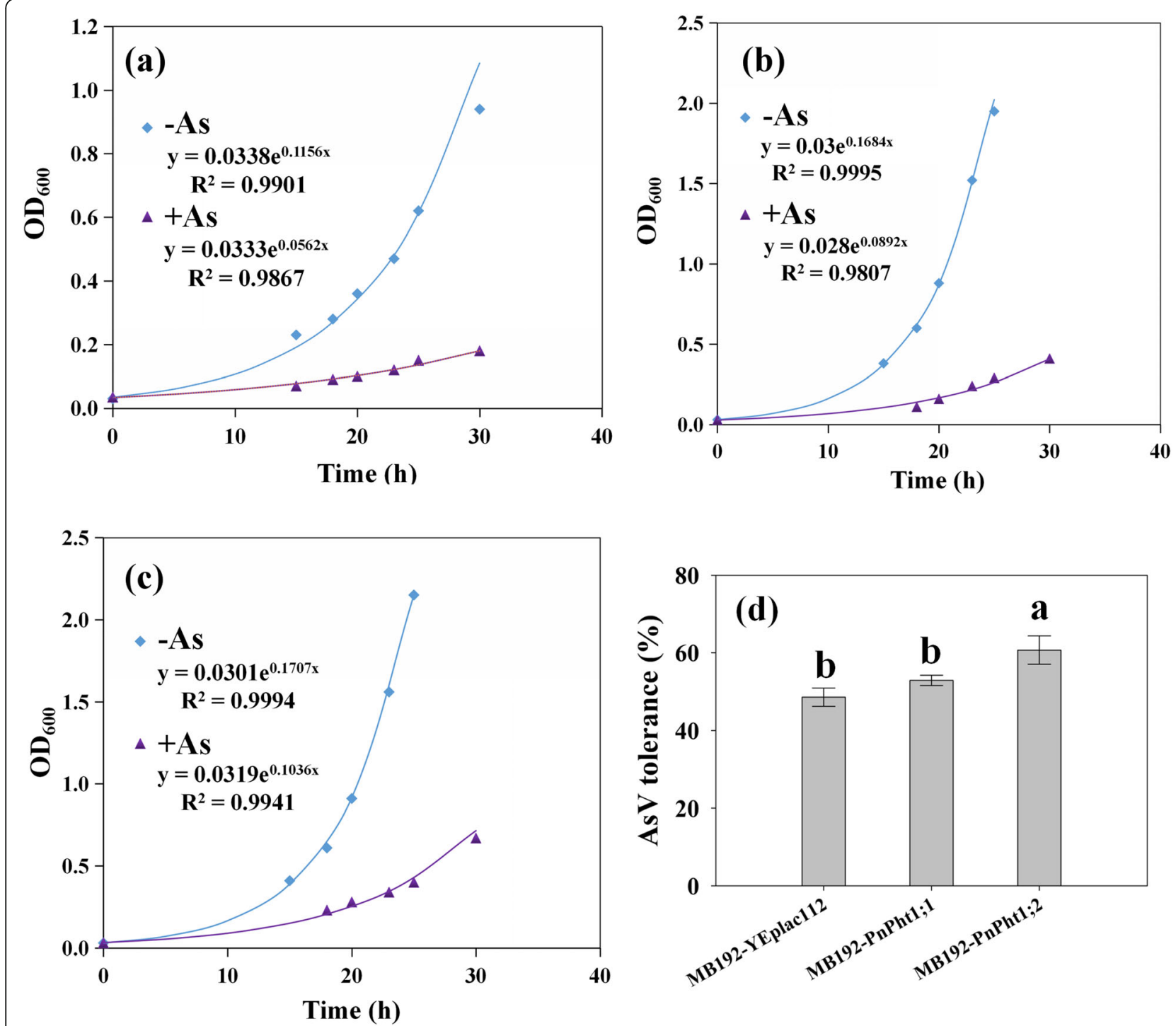

Fig. 7 Growth rates and As tolerance of cells expressing PnPht1;1 or PnPht1;2 supplement with $50 \mu \mathrm{M}$ Pi. Measurements of $\mathrm{OD}_{600}$ during logarithmic growth were used to generate exponential trend lines $\left(y(t)=a \times e^{k t}\right)$, where $k$ is the growth rate coefficient. $\mathbf{a}$ Growth rates of cells expressing vector supplement with (+As) or without (-As) $80 \mu \mathrm{M}$ AsV. b Growth rates of cells expressing PnPht 1;1 supplement with (+As) or without (-As) $80 \mu \mathrm{M}$ AsV. c Growth rates of cells expressing PnPht1;2 supplement with (+As) or without (-As) $80 \mu \mathrm{M}$ AsV. d As tolerance (\%) indicated by the proportional growth rate of the each transgenic yeast line in the presence of AsV compared with control growth. Different lowercase letters represent the difference of As tolerance among cells, $P \leq 0.05$. Values are the mean $\pm \mathrm{SD}(n=4)$

exposure [13]. Occasionally, Pi transporters showed little ability to transport AsV, e.g., PvPht1;2 in P. vittata [40]. Hence, further research is warranted to elucidate the properties that are likely to regulate $P n P h t 1 ; 1$ and $P n P h t 1$; 2.

Subsequently, the properties of PnPht1;1 and PnPht1;2 were analyzed through complementation assays in yeast mutant MB192 knocked out for high-affinity Pi transporterencoding genes. Yeast cells expressing PnPht1;1 and PnPht1;2 could complement the defect of the loss of highaffinity Pi transporters, growing well under low-Pi concentrations (2 and $20 \mu \mathrm{M}$ Pi) (Fig. 5). The results of $\mathrm{pH}$ - dependent and ACP activity assays showed that both PnPht1;1 and PnPht1;2 are $\mathrm{H}^{+}$dependent-type Pi transporters, which are driven by $\mathrm{H}^{+}$concentration gradients. Yeast cells expressing PnPht1;1 or PnPht1;2 were significantly inhibited in medium supplemented with CCCP or 2, 4-DNP, which are typical protonophores, resulting in the inhibition of anion uptake [41]. This finding is consistent with previous reports that many Pht 1 proteins are usually $\mathrm{H}^{+}$/ $\mathrm{H}_{2} \mathrm{PO}_{4}{ }^{-}$symporters and are involved in energy-dependent transport at the plasma membrane, mediating Pi uptake [9, 12, 39, 42, 43]. This confirmed our analysis of the localization of PnPht1;1 and PnPht1;2 (Fig. 3). However, the 

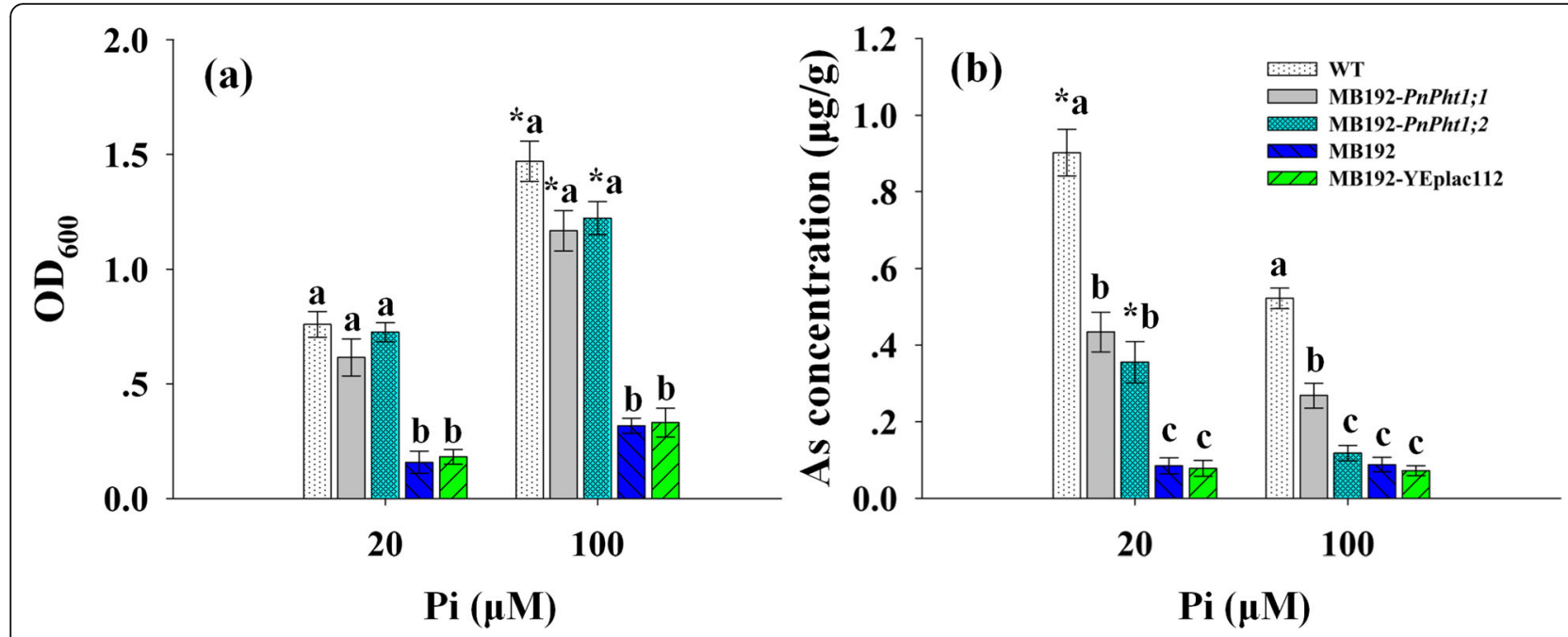

Fig. 8 Growth (a) and As accumulated concentration (b) of cells expressing PnPht1;1, PnPht 1;2 and vector under the $80 \mu M$ AsV stress supplement with low $(20 \mu \mathrm{M})$ or high $(100 \mu \mathrm{M})$ Pi. Different lowercase letters represent the difference among cells under the same Pi concentration, $P \leq 0.05$. ${ }^{*}$ represents the difference of the same cells between $20 \mu \mathrm{M}$ and $100 \mu \mathrm{M} \mathrm{Pi}, P \leq 0.05$. Error bars indicate mean values \pm SD, $(n=4)$

process of $\mathrm{H}^{+} / \mathrm{H}_{2} \mathrm{PO}_{4}{ }^{-}$symport in the membrane has not been determined, likely due to the mechanism of proton and glycerol-3-phosphate symport in E. coli [39, 44, 45].

As described above, there is a complicated relationship between $\mathrm{AsV}$ and Pi uptake and translocation. AsV in the cytoplasm competes with $\mathrm{Pi}$, forming an unstable complex of ADP-AsV, thereby disrupting the energy flow [46, 47]. Therefore, a high level of Pi supply to As-treated plants could decrease membrane damage by lowering oxidative injury [48]. In the plantation experiments, studies find that Pi supply could suppress As uptake by plants [26, 49-51], which is in line with our result as described in Figure S1. In addition, our results suggested that yeast cells expressing PnPht1;1 and PnPht1;2 improved As tolerance, particular in $P n P h t 1 ; 2$ with a significant difference by comparison to MB192-vector, indicating by growth rate coefficients and the As tolerance index (Fig. 7). In addition, cells harboring PnPht1;2 had a stronger AsV tolerance, while PnPht1;1-expressing cells accumulated more arsenic (Fig. 8b). An assumption was concluded that PnPht1;1 preferred to combine AsV compared to PnPht1; 2. Besides, an interesting phenomenon was shown that As concentrations in transformants harboring PnPht1;1 or $P n P h t 1 ; 2$ were significantly less than WT. It may be related to the difference of genetic characteristic between PHO84 knocked out in mutant and the two target genes. PHO84-overexpressing in Saccharomyces cerevisiae obviously enhanced the uptake of AsV [52]. In summary, as complementary mutant strains, the capability of MB192PnPht1;1 and MB192-PnPht1;2 of assimilating Pi or AsV is relatively weaker by comparison with WT. These observations are in line with previous studies and collectively suggest that high-affinity Pi transporters have comparable specificities for AsV uptake and play important roles in the enhanced AsV uptake and tolerance, e.g., PvPht1;3 in P. vittata [13] and OsPT1 in O. sativa [15]. As a highaffinity Pi transporter, pht1;1-3 in $A$. thaliana displays a slow rate of AsV uptake that ultimately enables the mutant to accumulate two times the arsenic found in wildtype plants [35], while AtPht1;5 or AtPht1;7 also have a preference for Pi over AsV [13]. In contrast, although OsPT8 was found to have a high affinity for both $\mathrm{Pi}$ and $\mathrm{AsV}, \mathrm{Wu}$ et al. considered that the Pi transporter contributed only slightly to As uptake [14]. Taken together, both PnPht1;1 and PnPht1;2 responded to the stresses of Pi deficiency or As exposure and improved the tolerance of AsV, particularly in a high level of Pi concentration. Many efforts need to be made to research the possibility of using the Pht genes in $P$. notoginseng to improve the adaptability to the stresses of Pi deficiency or As exposure, e.g., the construction of stable PnPht1;1- or PnPht1;2-overexpression system in $P$. notoginseng.

\section{Conclusions}

In this study, we uncovered the roles of PnPht1;1 and PnPht1;2 of P. notoginseng in the uptake of Pi and AsV. The results of qPCR showed that $P_{n} P h t 1 ; 1$ and $P_{n} P h t 1 ; 2$ responded to the Pi deficiency or As exposure and were highly upregulated. However, the expression levels of PnPht1;1 or PnPht1;2 decreased under supplementation with sufficient phosphate. Heterologous expression in Saccharomyces cerevisiae MB192 revealed that PnPht1;1 and $P n P h t 1 ; 2$ performed optimally in complementing the yeast Pi-transport defect, particularly in PnPht1;2. Cells expressing PnPht1;2 had a stronger AsV tolerance than PnPht1;1-expressing cells, and accumulated less As 
in cells under a high-Pi concentration. In addition, Pi supply could suppress As accumulation in the roots of $P$. notoginseng. Taken together, we confirmed that $P_{n} P h t 1 ; 1$ and $P n P h t 1 ; 2$ encoded functional plasma membrane-localized transporter proteins that mediated a putative high-affinity $\mathrm{Pi} / \mathrm{H}^{+}$symport activity. Expression of $P n P h t 1 ; 1$ or $P n P h t 1 ; 2$ in mutant strains could enhance the uptake of $\mathrm{Pi}$ and $\mathrm{AsV}$, that is probably responsible for the As accumulation of $P$. notoginseng.

\section{Methods}

\section{$P$. notoginseng material and experimental setup}

All $P$. notoginseng seedlings used in this study were bought from Wenshan Miaoxiang Sanqi Technology Co. LTD, and were identified by professor Ronghua Zhao, who is specialized in identification, cultivation and processing of Chinese herbs.

One-year-old $P$. notoginseng in good condition, cultivated in a standard planting garden were transplanted into garden pots. There was no significant difference in weight, height or leaf number of these seedlings. The cultivation medium was sandy loam texture, including $20 \%$ lightweight aggregate, $40 \%$ expanded vermiculite, $30 \%$ clay and $10 \%$ silt, modified according to Mandal et al. [53]. The concentration of dissolved $\mathrm{P}$ in the soil was decreased to $0.07 \mathrm{mM}$ through double rinsing with $1 \% \mathrm{NaHCO}_{3}$. The Pi concentration was adjusted to $0.07 \mathrm{mM}, 0.7 \mathrm{mM}$ and $1.4 \mathrm{mM}$ (in dry weight) via adding $\mathrm{KH}_{2} \mathrm{PO}_{4}$, which are minimally limited, growth-promoting and excessive concentrations for $P$. notoginseng. The 3 concentration treatments were referred to as low phosphate (IP), middle phosphate $(\mathrm{mP})$ and high phosphate $(\mathrm{hP})$. Before planting, sodium arsenate $\left(\mathrm{Na}_{3} \mathrm{AsO}_{4}\right)$ was blended into mixed soil with the additive amount of $0.2 \mathrm{mM}$ (in dry weight). The As concentration was as high as the background value of soil at the main producing areas in the Wenshan Autonomous Prefecture Yunnan Province [4]. In the experiment, 5 treatments were set up in total, as follows: $1 \mathrm{PnAs}$, IPhAs, mPhAs, hPnAs, and hPhAs. Meanwhile, mPnAs were taken as a control check (CK). Due to the absence of mineral nutrition in mixed soil, $50 \mathrm{~mL}$ 1/4 Hoagland's solution lacking phosphorus was used to nourish the plants every 3 days, in which $\mathrm{KH}_{2} \mathrm{PO}_{4}$ was replaced by $\mathrm{KNO}_{3}$. P. notoginseng grew at $25^{\circ} \mathrm{C}, 85 \%$ relative humidity, avoiding direct sunlight and water-accumulated in the greenhouse. After 5 months, the fresh fibrous roots were harvested, rinsed with deionized water, frozen in liquid nitrogen, and stored at $-80^{\circ} \mathrm{C}$. Each treatment had eight biological replicates and four plants in every replicate.

\section{Analysis of total As concentration in the rhizome of $P$. notoginseng}

The total As concentration in the rhizome of $P$. notoginseng was determined as described by Wu et al. [14] and Xu et al.
[54]. Plant samples were ground to fine powders and digested with $\mathrm{HNO}_{3}: \mathrm{H}_{2} \mathrm{O}_{2}(85: 15$, v/v). Then, the digestion solution was determined using inductively coupled plasma mass spectrometry (ICP-MS) (Agilent 7500c, USA).

\section{Clones of PnPht1;1 and PnPht1;2}

The open reading frame (ORF)'s base-pair information of PnPht1;1 and PnPht1;2 were obtained from a transcript of $P$. notoginseng roots treated as described above. The primers of PnPht1;1 and PnPht1;2 for the ORF clone are listed in Table 1. First-strand cDNA was used as a template for ORF PCR amplification, which was reverse-transcribed from total RNA with a Primescript II 1st strand cDNA synthesis kit (Takara, Japan). Total RNA was extracted from the fibrous roots with the miniBEST plant RNA extraction kit (TaKaRa, Japan). PCR procedures comprised an initial denaturation step $\left(94^{\circ} \mathrm{C} / 5 \mathrm{~min}\right)$ followed by 35 cycles of $94{ }^{\circ} \mathrm{C} / 1 \mathrm{~min}, 58^{\circ} \mathrm{C} / 30 \mathrm{~s}, 72{ }^{\circ} \mathrm{C} / 1 \mathrm{~min}$, and holding at $4{ }^{\circ} \mathrm{C}$. The sequences have been submitted to NCBI, of which the GenBank accession numbers for PnPht1;1 and PnPht1;2 are MN420501 and MN420502.

\section{qPCR}

Total RNAs in fibrous roots of 5 treatment groups (IPnAs, lPhAs, mPhAs, hPnAs, hPhAs) and control check (mPnAs) were extracted as described above. As a template, cDNA was reverse-transcribed with Primescript RT reagent kit with gDNA eraser (TaKaRa, Japan). All qPCRs were performed with TB Green Premix Ex Taq (Tli RNaseH Plus), ROX plus (TaKaRa, Japan) with the genespecific primers (Table 1) according to the manufacturer's instructions. Each $20 \mu \mathrm{L}$ reaction system contained $10 \mu \mathrm{L}$ TB Green mix, $100 \mathrm{ng}$ cDNA and $0.2 \mu \mathrm{M}$ of each primer. 26S-2 was targeted as the reference gene and used for normalization of RT-qPCR data [55]. The primer pair is shown in Table 1 . In the end, relative transcription levels were estimated using the $2^{-\Delta \Delta \mathrm{Ct}}$ method [56].

\section{Bioinformatics analysis}

The ORF of the full-length cDNA was identified using online software at https://www.ncbi.nlm.nih.gov/orffinder/. The location of hydrophobic, isoelectric point, protein molecular weight, and putative transmembrane domains were enabled through the software package mounted at http://expasy.org/tools/protscale.html. Multiple peptide alignments were carried out using DNAman (DNAman v6.0, Lynnon Biosoft, USA). Phylogenetic analyses used MEGA v4.0 software.

\section{Complementation of a yeast mutant strain defective for Pi uptake}

Saccharomyces cerevisiae MB192 (MATa pho3-1 pho84::HIS3 ade2 leu2-3, 112 his3-532, trp1-289 ura31, 2 can1) defective in the high-affinity $\mathrm{Pi}$ transporter 
Table 1 Specific primer pairs used for ORF cloning, qPCR, and recombinant plasmid construction. 26S-2 was used as an internal control genes

\begin{tabular}{|c|c|c|}
\hline Genes & Primers $\left(5^{\prime}-3^{\prime}\right)$ & Usage \\
\hline \multirow[t]{2}{*}{ PnPht1;1 } & F: ATGTCTGGGAATAATCTGCAGG & \multirow[t]{4}{*}{ to amplify cDNA ORF } \\
\hline & R: CTAAACTTGTGCCTCATTTGCA & \\
\hline \multirow[t]{2}{*}{ PnPht1;2 } & F: ATGGCTCGAGAGCAACTAGAAG & \\
\hline & R: TTATACCGGCACAGTCCTGTTAG & \\
\hline \multirow[t]{2}{*}{ qPnPht1;1 } & F:GAACGGGAATTTTGGTTGCTG & \multirow{6}{*}{$\begin{array}{l}\text { to amplify segments for } \\
\text { qPCR }\end{array}$} \\
\hline & R:AAGTCGCCTTGTGGCTGAGTG & \\
\hline \multirow[t]{2}{*}{ qPnPht1;2 } & F:GCGCGTTTATAGCGGCTGTTT & \\
\hline & R:ACTTTTGCCTCTTGGGGGTCA & \\
\hline \multirow[t]{2}{*}{ 26S-2(reference gene) } & F:CAGTATTTAGCCTTGGACGGAATT & \\
\hline & R:CGGGTTGTTTGGGAATGC & \\
\hline \multirow[t]{2}{*}{ SPnPht1;1(BamH I/Kpn I) } & F: CGCGGATCCATGTCTGGGAATAATCTGCAGG & \multirow{4}{*}{$\begin{array}{l}\text { to amplify genes for } \\
\text { recombinant plasmid } \\
\text { construction in S. cerevisiae }\end{array}$} \\
\hline & R: CGGGGTACCCTAAACTTGTGCCTCATTTGCA & \\
\hline \multirow[t]{2}{*}{ SPnPht1;2(Xba I/ Xma I) } & F: TGCTCTAGAATGGCTCGAGAGCAACTAGAAG & \\
\hline & R:TCCCCCCGGGTTATACCGGCACAGTCCTGTTAG & \\
\hline \multirow[t]{2}{*}{ NbPnPht1;1(BamH I/Sal I) pENTR } & F:GAGAACACGGGGGACTGGTACCCGGGGATCCATGTCTGGGAATAATCTGCAGG & \multirow{6}{*}{$\begin{array}{l}\text { to amplify genes for } \\
\text { recombinant plasmid } \\
\text { construction in } N \text {. } \\
\text { benthamiana }\end{array}$} \\
\hline & R:ACAGCTCCTCGCCCTTGCTCACCATGTCGACAACTTGTGCCTCATTTGCATCCT & \\
\hline \multirow[t]{2}{*}{ NbPnPht 1;2(BamH I/Sal I) pENTR } & F:GAGAACACGGGGGACTGGTACCCGGGGATCCATGGCTCGAGAGCAACTA & \\
\hline & R:ACAGCTCCTCGCCCTTGCTCACCATGTCGAC ACGAATGGCCCTTITATCC & \\
\hline \multirow[t]{2}{*}{ NbUPF0057(BamH I/Sal I) pENTR } & F:GAGAACACGGGGGACTGGTACCCGGGGATCCATGGTCTCAAGATGTGCA & \\
\hline & R:ACAGCTCCTCGCCCTTGCTCACCATGTCGACAGCAAGAGTGTCATAACG & \\
\hline
\end{tabular}

gene PHO84 by insertion of an HIS3 DNA fragment was chosen as a heterologous expression yeast for uptakefunctional verification of $\mathrm{Pi}$ and As $[11,57]$. The ORFs of PnPht1;1 and PnPht1;2 were amplified using TransStart FastPfu DNA Polymerase (Transgen Biotech, China) with the primer pairs containing restriction enzyme cutting sites (Table 1). The resulting amplicons were digested with the corresponding enzymes $\mathrm{BamH} \mathrm{I} /$ $K p n \mathrm{I}$ and Xba I/Xma I and then introduced into the expression vector YEplac112 with their respective recognition sites using T4 DNA Ligase (NEB, USA) following the manufacturer's protocol. The structure of the resulting recombinant plasmids were defined by restriction enzyme digestion and DNA sequencing with $E$. coli (DH5 $\alpha)$. Two recombinant plasmids and empty vector YEplac112 were transformed into MB192 cells by electrotransformation using the Bio-Rad electroporation equipment (Bio-Rad Laboratories, Richmond, USA) [58]. In total, 3 transformants, including MB192-PnPht1;1, MB192-PnPht1;2 and MB-YEplac112 were yielded. Wild-type (WT) S. cerevisiae was used as a positive control. Positive transformants were picked out through SD-Trp ${ }^{-}$selective medium. Monoclonal cells were transferred into yeast nitrogen base (YNB) liquid medium supplemented with $4.5 \mu \mathrm{M} \mathrm{Pi}$, and the recombinant plasmids were verified through plasmid extraction and sequencing.

For the effect of $\mathrm{Pi}$ concentration, identified yeasts were re-cultured to the logarithmic phase $\left(\mathrm{OD}_{600}=0.6\right)$ in the YNB liquid medium. Then, $100 \mu \mathrm{L}$ of suspension liquid was diluted to $5 \mathrm{~mL}$ and cultured at $200 \mathrm{rpm}$ and $30{ }^{\circ} \mathrm{C}$ for an additional $16 \mathrm{~h}$, in which the medium was adjusted with a range of $\mathrm{Pi}$ concentrations (0.002, 0.02, 0.06 , and $0.1 \mathrm{mM}$ ) and an initial $\mathrm{pH}$ of 6.8 [38]. Bromocresol purple was used to indicate the change of $\mathrm{pH}$, which gave a color shift from yellow to purple. During the acidification of the liquid medium, the change correlated well with the growth of the yeast cells and acid phosphatase activity (ACP) [59]. For pH-dependent $\mathrm{Pi}$ uptake experiments, the $\mathrm{pH}$ value in the medium was in the range of 4.0 to 8.0 . In the tests, monoclonal cells were transferred into YNB liquid medium containing $80 \mu \mathrm{M} \mathrm{Pi}$ and cultured for $24 \mathrm{~h}$ at $200 \mathrm{rpm}$ and $30^{\circ} \mathrm{C}$. For the growth assays, the $\mathrm{OD}_{600}$ of yeast cells was determined every 3 or $5 \mathrm{~h}$ in $5 \mathrm{~mL} \mathrm{SD-Trp}{ }^{-}$medium containing $20 \mu \mathrm{M} \mathrm{Pi}$ and $2 \%$ glucose at $200 \mathrm{rpm} 30^{\circ} \mathrm{C}$, adjusting the $\mathrm{pH}$ to 6 and the initial concentration of $\mathrm{OD}_{600}$ to 0.03 with a cell suspension of the logarithmic phase [13]. Thus, growth rate coefficients of the logarithmic growth were calculated via exponential regression. 


\section{Effect of respiratory inhibitors on Pi uptake}

When the $\mathrm{OD}_{600}$ of yeast suspension harboring PnPht1; 1 or $P n P h t 1 ; 2$ was up to $0.6,100 \mu \mathrm{L}$ yeast suspension was inoculated into $5 \mathrm{~mL} \mathrm{SD-Trp}{ }^{-}$medium containing

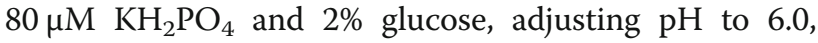
with or without carbonyl cyanide $m$-chlorophenylhydrazone (CCCP) $(10$ or $50 \mu \mathrm{M})$, and 2,4-dinitrophenol (2,4DNP) $(100$ or $200 \mu \mathrm{M})[39,60]$. CCCP was initially dissolved in ethanol and added to the medium to a final ethanol concentration of $0.01 \%(\mathrm{v} / \mathrm{v})$ [61]. Optical density $\left(\mathrm{OD}_{600}\right)$ was measured after cultivation with shaking at $200 \mathrm{rpm}$ for $20 \mathrm{~h}$ and at $30^{\circ} \mathrm{C}$.

\section{AsV uptake affected by Pi concentration}

For the assays of growth rates and As tolerance, cells expressing PnPht1;1, PnPht1;2 or YEplac112 were washed

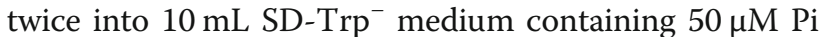
and $2 \%$ glucose, which made an initial concentration of $0.03\left(\mathrm{OD}_{600}\right)$. Then, AsV was added to the medium at a final concentration of $80 \mu \mathrm{M}$ before culturing at $200 \mathrm{rpm}$ and $30^{\circ} \mathrm{C}$ for $30 \mathrm{~h}$. The $\mathrm{OD}_{600}$ of yeast cells was determined every 3 or $5 \mathrm{~h}$ to uncover growth rate coefficients and $\mathrm{AsV}$ tolerance at the logarithmic phase [13]. The uptake affected by Pi concentration was investigated by determining the $\mathrm{OD}_{600}$ and As accumulation concentration in cells. First, $1 \mathrm{~mL}$ of $\mathrm{OD}_{600}=0.6$ suspensions of transformants and WT were transferred into $50 \mathrm{~mL} \mathrm{SD-}$ $\mathrm{Trp}^{-}$medium containing $2 \%$ glucose, different $\mathrm{Pi}$ concentrations $(20$ or $100 \mu \mathrm{M})$ and $80 \mu \mathrm{M} \mathrm{AsV}$, adjusting the $\mathrm{pH}$ to 6.0. The $\mathrm{OD}_{600}$ of the yeast suspension was measured after cultivation with shaking at $200 \mathrm{rpm}$ for $30 \mathrm{~h}$ and at $30^{\circ} \mathrm{C}$. Then, yeast cells were collected at $5000 \mathrm{rpm}$ for $5 \mathrm{~min}$, and the pellets were washed twice with $25 \mathrm{~mL} 10 \mathrm{mM}$ EDTA [62]. After digestion as described above, total As was determined using ICP-MS (Agilent 7500c, USA). Data collected were performed with four biological replicates, and three technical replications of each biological replicate were conducted independently.

\section{Subcellular localization of $P$ nPht 1;1 and PnPht1;2}

$P n P h t 1 ; 1$ and PnPht1;2 were cloned into a pCOMBIA 1301 GFP binary vector (Wuhan Stargene, China), containing $35 \mathrm{~S}$ promoter, GFP and $\mathrm{Kan}^{+}$resistance genes using $\mathrm{Bam} \mathrm{H} / \mathrm{Sal}$ I recognition sites. Meanwhile, the $\mathrm{N}$. tabacum plasma membrane protein UPF0057 gene (XM_016579128.1), used as a membrane specificlocation gene, was also cloned into the above modified binary vector (where GFP only is replaced by RFP) via Bam H/Sal I sites. The above 3 recombinant plasmids were transformed into DH5 $\alpha$ E. coli competent cells (CD101, Transgene biotech, China). Then, the positive clones were picked, sequenced and verified. The recombinant plasmids were transferred to Agrobacterium tumefaciens EHA105 by the freeze-thaw method [63]. A. tumefaciens EHA105 harboring recombinant plasmids were infiltrated into the leaves of four-week-old $N$. benthamiana through lower epidermis injection of $1 \mathrm{~mL}$ bacterium suspension. The cells were finally induced at 4-6 days after infiltration with $10 \mu \mathrm{M} \beta$-estradiol (Sigma) for $6-12 \mathrm{~h}$ and the transient expression analyses were performed as described by Dong et al. [64]. Images were obtained using an UltraVIEW VoX laser doublespinning disk confocal real-time imaging analysis microscope (PerkinElmer, USA). Autoluminescence, GFP, and RFP were excited by a 640, 488 and $561 \mathrm{~nm}$ laser, respectively.

\section{Statistical analysis}

All data were processed and analyzed statistically with Microsoft Excel 2010, SPSS 17.0, and Sigmaplot 12.0 for Windows. Assumptions of normality and homogeneity of variances were tested prior to all statistical tests. The significant differences were all tested with one-way analysis of variance (ANOVA) followed by Tukey HSD tests at the 0.05 level, including relative expression level (Fig. 4), ACP activity (Fig. 5c), OD 600 (Figs. 5d and 8a), As concentration (Fig. 8b, Figure S1) and growth rate coefficient (Fig. 6d). In addition, an independent-samples ttest at the 0.05 or 0.01 level was also used to analyze the difference, e.g., $\mathrm{OD}_{600}$ between each treatment (CCCP or 2,4-DNP) and CK (Fig. 5e), $\mathrm{OD}_{600}$ or As concentration between $20 \mu \mathrm{M}$ and $100 \mu \mathrm{M}$ Pi (Fig. 8). All data in figures and tables are expressed as the means \pm standard deviation (SD, $n \geq 3$ ).

\section{Supplementary information}

Supplementary information accompanies this paper at https://doi.org/10. 1186/s12870-020-2316-7.

Additional file 1: Figure S1. As concentration in the roots of Panax notoginseng treated with different concentrations of Pi and AsV. IPnAs (0.07 mM Pi and non-AsV), IPhAs (0.07 mM Pi and 0.2 mM AsV), mPnAs (0.7 mM Pi and non-AsV), mPhAs (0.7 mM Pi and 0.2 mM AsV), hPnAs (1.4 $\mathrm{mM} \mathrm{Pi}$ and non-AsV), and hPhAs (1.4 mM Pi and $0.2 \mathrm{mM} \mathrm{AsV).} \mathrm{Different}$ lowercase letters represent the difference among treatment groups, $P \leq$ 0.05 . Error bars indicate mean values $\pm \mathrm{SD},(n=4)$.

\section{Abbreviations}

2,4-DNP: 2,4-dinitrophenol; ACP: Acid phosphatase activity; ADP: Adenosine diphosphate; ANOVA: Analysis of variance; As: Arsenic; AsV: Arsenate;

CCCP: Carbonyl cyanide m-chlorophenylhydrazone; CK: Control check; Co. LTD: Company limited; EDTA: Ethylenediaminetetraacetic acid; GFP: Green fluorescent protein; hP: High phosphate; hPhAs: High phosphate and high arsenate; hPnAs: High phosphate and non-arsenate; ICP-MS: Inductively coupled plasma mass spectrometry; IP: Low phosphate; IPhAs: Low phosphate and high arsenate; IPnAs: Low phosphate and non-arsenate; mP: Middle phosphate; mPhAs: Middle phosphate and high arsenate; mPnAs: Middle phosphate and non-arsenate; OD: Optical density; ORF: Open reading frame; P: Phosphorus; PCR: Polymerase chain reaction; Pi: Phosphate; qPCR: Real-time quantitative PCR; RFP: Red fluorescent protein; SD: Standard deviation; SD-Trp ${ }^{-}$: Synthetic dropout medium of tryptophan; WT: Wild type; YNB: Yeast nitrogen base 


\section{Acknowledgments}

We are thankful to Zhi-Wei Zhao (State Key Laboratory of Conservation and Utilization for Bioresources in Yunnan, Yunnan University) for providing strain of Saccharomyces cerevisiae MB192.

\section{Authors' contributions}

SH, JY and GC conceived and designed the experiments. DL, GC, XZ, XW, DC and WG performed experiments, analysed data etc. RZ helped with material preparation. GC, SH and JY contributed to the writing of this manuscript. All authors read and approved the final manuscript.

\section{Funding}

This study was financially supported by the National Natural Science Foundation of China (81560612), Yunnan Basic Research Projects (2019FB122), State Key Laboratory of Conservation and Utilization for Bioresources in Yunnan (2017KF006), and the Yunnan Provincial Science and Technology Department---- Applied Basic Research Joint Special Funds of Yunnan University of Chinese Medicine (2017FF116 (- 019); 2017 FF117 (014)). This study was also partly supported by the Youth Foundation of Yunnan Applied Basic Research Projects (2017FD109), the National Key Research and Development Program (2017YFC1700704), the Project of Collaborative Innovation Research Center of Southern Medicine (30272100800), and the Major Expenditure Increase and Reduction Projects at the central Level (2060302). The funding agencies had no role in the experimental design, data collection and analysis or preparation of the manuscript.

\section{Availability of data and materials}

The data generated or analyzed during this study are included in this published article and its supplementary information file. The GenBank accession numbers of PnPht1:1 and PnPht1:2 are MN420501 and MN420502.

\section{Ethics approval and consent to participate}

Not applicable.

\section{Consent for publication}

Not applicable.

\section{Competing interests}

The authors declare that they have no competing interests.

\section{Author details}

${ }^{1}$ College of Traditional Chinese Medicine, Yunnan University of Chinese Medicine, Kunming, Yunnan, China. ${ }^{2}$ State Key Laboratory of Conservation and Utilization for Bioresources in Yunnan, Yunnan University, Kunming, Yunnan, China.

Received: 8 November 2019 Accepted: 27 February 2020

Published online: 20 March 2020

\section{References}

1. Yan $X L$, Lin LY, Liao XY, Zhang WB. Arsenic accumulation and resistance mechanism in Panax notoginseng, a traditional rare medicinal herb. Chemosphere. 2012;87(1):31-6

2. Lin $L Y$, Yan $X L$, Liao $X Y$, Zhang $Y X$, Ma X. Arsenic accumulation in Panax notoginseng monoculture and intercropping with Pteris vittata. Water Air Soil Pollut. 2015;226(4):113.

3. Ou X, Wang L, Guo L, Cui X, Liu D, Yang Y. Soil-plant metal relations in panax notoginseng: an ecosystem health risk assessment. Int J Environ Res Public Health. 2016;13(11):1089.

4. Feng GQ, Liu YZ, Zhang WB, Wu ZC. Research on polluted channel of arsenic in the Panax notoginseng. J Chin Med Mater. 2005;28(8):645-7 (in (hinese).

5. Lin LY, Yu BB, Liao XY, Yan XL, Zhang YX. Contents and health risk of as and heavy metals in Panax notoginseng and their pharmaceutical preparations. Asian J Ecotox. 2013;82:244-9 (in Chinese).

6. Liu XJ, Zhao QL, Sun GX, Williams P, Lu XJ, Cai JZ, Liu WJ. Arsenic speciation in Chinese herbal medicines and human health implication for inorganic arsenic. Environ Pollut. 2013;172:149-54.
7. Liu D, Xu N, Wang L, Cui X, Guo L, Zhang Z, Wang J, Yang Y. Effects of different cleaning treatments on heavy metal removal of Panax notoginseng (Burk) F. H. Chen. Food Addit Contam. 2014;31(12):2004-13.

8. Vithanage M, Dabrowska BB, Mukherjee AB, Sandhi A, Bhattacharya P. Arsenic uptake by plants and possible phytoremediation applications: a brief overview. Environ Chem Lett. 2012;10(3):217-24.

9. Remy E, Cabrito TR, Batista RA, Teixeira MC, Sá-Correia I, Duque P. The pht1; 9 and pht1;8 transporters mediate inorganic phosphate acquisition by the Arabidopsis thaliana root during phosphorus starvation. New Phytol. 2012; 195(2):356-71.

10. Ullrich-Eberius $\mathrm{Cl}$, Novacky A, Fischer E, Luttge U. Relationship between energy-dependent phosphate uptake and the electrical membrane potential in Lemna gibba G1. Plant Physiol. 1981;67(4):797-801.

11. Qin L, Guo YX, Chen LY, Liang RK, Gu M, Xu GH, Zhao J, Walk T, Liao H. Functional characterization of 14 pht1 family genes in yeast and their expressions in response to nutrient starvation in soybean. PLoS One. 2012; 7(10):e47726.

12. Doki S, Kato HE, Solcan N, Iwaki M, Koyama M, Hattori M, Newstead S. Structural basis for dynamic mechanism of proton-coupled symport by the peptide transporter POT. PNAS. 2013;110(28):11343-8.

13. Ditusa SF, Fontenot EB, Wallace RW, Silvers MA, Steele TN, Elnagar AH, Dearman KM, Smith AP. A member of the phosphate transporter 1 (pht1) family from the arsenic-hyperaccumulating fern Pteris vittata is a highaffinity arsenate transporter. New Phytol. 2016;209(2):762-72.

14. Wu Z, Ren H, McGrath SP, Wu P, Zhao FJ. Investigating the contribution of the phosphate transport pathway to arsenic accumulation in rice. Plant Physiol. 2011;157(1):498-508.

15. Kamiya T, Islam R, Duan G, Uraguchi S, Fujiwara T. Phosphate deficiency signaling pathway is a target of arsenate and phosphate transporter, ospt1, is involved in as accumulation in shoots of rice. Soil Sci Plant Nutr. 2013; 59(4):580-90.

16. Wang $P$, Zhang W, Mao C, Xu G, Zhao FJ. The role of ospt8 in arsenate uptake and varietal difference in arsenate tolerance in rice. J Exp Bot. 2016; 67(21):6051-9.

17. Ye Y, Li P, Xu T, Zeng L, Cheng D, Yang M, Luo J, Lian X. OsPT4 contributes to arsenate uptake and transport in rice. Front Plant Sci. 2017:8:2197.

18. Christophersen HM, Smith FA, Smith SE. Arbuscular mycorrhizal colonization reduces arsenate uptake in barley via downregulation of transporters in the direct epidermal phosphate uptake pathway. New Phytol. 2009;184(4):96274.

19. Puckett EE, Serapiglia MJ, Deleon AM, Long S, Minocha R, Smart LB. Differential expression of genes encoding phosphate transporters contributes to arsenic tolerance and accumulation in shrub willow (salix spp.). Environ Exp Bot. 2012;75:248-57.

20. Schachtman DP, Reid RJ, Ayling SM. Phosphorus uptake by plants: from soil to cell. Plant Physiol. 1998;116(2):447-53.

21. Chrispeels MJ, Crawford NM, Schroeder Jl. Proteins for transport of water and mineral nutrients across the membranes of plant cells. Plant Cell. 1999; 11(4):661-75.

22. Raghothama KG. Phosphate transport and signaling. Curr Opin Plant Biol. 2000;3(3):182-7.

23. Wang $X$, Wang $Y$, Piñeros MA, Wang Z, Wang W, Li C, Wu Z, Kochian LV, Wu P. Phosphate transporters OsPHT1;9 and OsPHT1;10 are involved in phosphate uptake in rice. Plant Cell Environ. 2014;37(5):1159-70.

24. Meharg AA, Hartley-Whitaker J. Arsenic uptake and metabolism in arsenic resistant and nonresistant plant species. New Phytol. 2002;154(1):29-43.

25. Geng CN, Zhu YG, Tong YP, Smith SE, Smith FA. Arsenate (As) uptake by and distribution in two cultivars of winter wheat (Triticum aestivum L.) Chemosphere. 2006;62(4):608-15.

26. Anawar HM, Rengel Z, Damon P, Tibbett M. Arsenic-phosphorus interactions in the soil-plant-microbe system: dynamics of uptake, suppression and toxicity to plants. Environ Pollut. 2018;233:1003-12.

27. Chen XW, Wu FY, Li H, Chan WF, Wu C, Wu SC, Wong MH. Phosphate transporters expression in rice (Oryza sativa L.) associated with arbuscular mycorrhizal fungi (amf) colonization under different levels of arsenate stress. Environ Exp Bot. 2013:87:92-9.

28. Zvobgo G, LwalabaWaLwalaba J, Sagonda T, Mapodzeke JM, Muhammad N, Haider Shamsi IH, Zhang G. Phosphate alleviates arsenate toxicity by altering expression of phosphate transporters in the tolerant barley genotypes. Ecotoxicol Environ Saf. 2018;147:832-9. 
29. Zhu YG, Geng CN, Tong YP, Smith SE, Smith FA. Phosphate (Pi) and arsenate uptake by two wheat (Triticum aestivum) cultivars and their doubled haploid lines. Ann Bot. 2006;98(3):631-6.

30. Karandashov $\vee$, Bucher M. Symbiotic phosphate transport in arbuscular mycorrhizas. Trends Plant Sci. 2005;10(1):22-9.

31. Wang NX, Li Y, Deng XH, Miao AJ, Ji R, Yang LY. Toxicity and bioaccumulation kinetics of arsenate in two freshwater green algae under different phosphate regimes. Water Res. 2013;47(7):2497-506.

32. Tang X, Lim MP, McBride MB. Arsenic uptake by arugula (Eruca vesicaria L.) cultivars as affected by phosphate availability. Chemosphere. 2018;195:55966.

33. Esteban E, Carpena RO, Meharg AA. High-affinity phosphate/As(V) transport in white lupin (Lupinus albus) is relatively insensitive to phosphate status. New Phytol. 2003;158(1):165-73.

34. Lei M, Wan XM, Huang ZC, Chen TB, Li XW, Liu YR. First evidence on different transportation modes of arsenic and phosphorus in arsenic hyperaccumulator Pteris vittata. Environ Pollut. 2012;161:1-7.

35. Catarecha P, Segura MD, Franco-Zorrilla JM, Garcia-Ponce B, Lanza M, Solano R, Paz-Ares J, Leyva A. A mutant of the Arabidopsis phosphate transporter pht1;1 displays enhanced arsenic accumulation. Plant Cell. 2007; 19(3):1123-33.

36. LeBlanc MS, McKinney EC, Meagher RB, Smith AP. Hijacking membrane transporters for arsenic phytoextraction. J Biotechnol. 2013;163(1):1-9.

37. Muehe EM, Eisele JF, Daus B, Kappler A, Harter K, Chaban C. Are rice (Oryza sativa L.) phosphate transporters regulated similarly by phosphate and arsenate? A comprehensive study. Plant Mol Biol. 2014;85(3):301-16.

38. Liu P, Chen S, Song A, Zhao S, Fang W, Guan Z, Liao Y, Jiang J, Chen F. A putative high affinity phosphate transporter, $\mathrm{Cmpt1}$, enhances tolerance to Pi deficiency of chrysanthemum. BMC Plant Biol. 2014;14(1):18.

39. Zhang L, Hu B, Li W, Che R, Deng K, Li H, Yu F, Ling H, Li Y, Chu C. Ospt2, a phosphate transporter, is involved in the active uptake of selenite in rice. New Phytol. 2014;201(4):1183-91.

40. Cao Y, Sun D, Chen JX, Mei H, Ai H, Xu G, Chen Y, Ma LQ. Phosphate transporter PvPht1;2 enhances phosphorus accumulation and plant growth without impacting arsenic uptake in plants. Environ Sci Technol. 2018;52(7): 3975-81.

41. Shioi J, Taylor BL. Oxygen taxis and proton motive force in Salmonella typhimurium. J Biol Chem. 1984;259(17):10983-8.

42. Wu C, Wang Q, Xue S, Pan W, Lou L, Li D, Hartley W. Do aeration conditions affect arsenic and phosphate accumulation and phosphate transporter expression in rice (Oryza sativa L.). Environ Sci Pollut R. 2018;25(1):43-51.

43. Huang KL, Wang $H$, Wei YL, Jia HX, Zha L, Zheng Y, Li XB. The high-affinity transporter BnPHT1;4 is involved in phosphorus acquisition and mobilization for facilitating seed germination and early seedling growth of Brassica napus. BMC Plant Biol. 2019;19(1):156.

44. Abramson J, Smirnova I, Kasho V, Verner G, Kaback HR, Iwata S. Structure and mechanism of the lactose permease of Escherichia coli. Science. 2003; 301(5633):610-5.

45. Huang YF, Lemieux MJ, Song JM, Auer M, Wang DN. Structure and mechanism of the glycerol-3-phosphate transporter from Escherichia coli. Science. 2003;301(5633):616-20.

46. Hartley-Whitaker J, Ainsworth GC, Meharg AA. Copper-and arsenate-induced oxidative stress in Holcus lanatus L. clones with differential sensitivity. Plant Cell Environ. 2001;24(7):713-22.

47. Hartley-Whitaker J, Woods C, Meharg AA. Is differential phytochelatin production related to decreased arsenate influx in arsenate tolerant Holcus lanatus. New Phytol. 2002;155(2):219-25.

48. Gunes A, Pilbeam DJ, Inal A. Effect of arsenic-phosphorus interaction on arsenic-induced oxidative stress in chickpea plants. Plant Soil. 2009;314(1-2): 211-20.

49. Kertulis GM, Ma LQ, MacDonald GE, Chen R, Winefordner JD, Cai Y. Arsenic speciation and transport in Pteris vittata $\mathrm{L}$. and the effects on phosphorus in the xylem sap. Environ Exp Bot. 2005;54(3):239-47.

50. Ye WL, Khan MA, McGrath SP, Zhao FJ. Phytoremediation of arsenic contaminated paddy soils with Pteris vittata markedly reduces arsenic uptake by rice. Environ Pollut. 2011;159(12):3739-43.

51. Yan X, Zhang M, Liao X, Tu S. Influence of amendments on soil arsenic fractionation and phyto availability by Pteris vittata L. Chemosphere. 2012; 88(2):240-4
52. Shen MW, Shah D, Chen W, Da Silva N. Enhanced arsenate uptake in Saccharomyces cerevisiae overexpressing the Pho84 phosphate transporter. Biotechnol Prog. 2012;28(3):654-61.

53. Mandal S, Upadhyay S, Wajid S, Ram M, Jain DC, Singh VP, Abdin MZ, Kapoo R. Arbuscular mycorrhiza increase artemisinin accumulation in Artemisia annua by higher expression of key biosynthesis genes via enhanced jasmonic acid levels. Mycorrhiza. 2015;25(5):345-57.

54. Xu J, Shi S, Wang L, Tang Z, Lv T, Zhu X, Ding X, Wang Y, Zhao F, Wu Z. Oshac4 is critical for arsenate tolerance and regulates arsenic accumulation in rice. New Phytol. 2017;215(3):1090-101.

55. Wu Q, Ma X, Zhang K, Feng X. Identification of reference genes for tissuespecific gene expression in Panax notoginseng using quantitative real-time PCR. Biotechnol Lett. 2014;37(1):197-204.

56. Livak KJ, Schmittgen TD. Analysis of relative gene expression data using real-time quantitative PCR and the $2^{-\Delta \Lambda C T}$ (-Delta Delta $\left.C(T)\right)$ method. Methods. 2001;25(4):402-8.

57. Bun-Ya M, Nishimura M, Harashima S, Oshima Y. The PHO84 gene of Saccharomyces cerevisiae encodes an inorganic phosphate transporter. Mol Cell Biol. 1991;11(6):3229-38.

58. Costaglioli P, Meilhoc E, Masson JM. High-efficiency electrotransformation of the yeast Schwanniomyces occidentalis. Curr Genet. 1994;27(1):26-30.

59. Jia H, Ren H, Gu M, Zhao J, Sun S, Zhang X, Chen J, Wu P, Xu G. The phosphate transporter gene ospht1;8 is involved in phosphate homeostasis in rice. Plant Physiol. 2011;156(3):1164-75.

60. Mitsukawa N, Okumura S, Shirano Y, Sato S, Kato T, Harashima S, Shibata D. Overexpression of an Arabidopsis thaliana high-affinity phosphate transporter gene in tobacco cultured cells enhances cell growth under phosphate-limited conditions. PNAS. 1997;94(13):7098-102.

61. Li HF, Steve PM, Zhao FJ. Selenium uptake, translocation and speciation in wheat supplied with selenate or selenite. New Phytol. 2008;178(1):92-102.

62. Gravot A, Lieutaud A, Verret F, Auroy P, Vavasseur A, Richaud P. AtHMA3, a plant P1B-ATPase, functions as a Cd/Pb transporter in yeast. FEBS Lett. 2004; 561(1-3):22-8.

63. van Herpen TWJM, Cankar K, Nogueira M, Bosch D, Bouwmeester HJ, Beekwilder J. Nicotiana benthamiana as a production platform for artemisinin precursors. PLoS One. 2010;5(12):e14222.

64. Dong L, Miettinen K, Goedbloed M, Verstappen FWA, Voster A, Jongsma MA, Memelink J, van der Krol S, Bouwmeester H. Characterization of two geraniol synthases from Valeriana officinalis and lippia dulcis: similar activity but difference in subcellular localization. Metab Eng. 2013;20:198-211.

\section{Publisher's Note}

Springer Nature remains neutral with regard to jurisdictional claims in published maps and institutional affiliations.

Ready to submit your research? Choose BMC and benefit from:

- fast, convenient online submission

- thorough peer review by experienced researchers in your field

- rapid publication on acceptance

- support for research data, including large and complex data types

- gold Open Access which fosters wider collaboration and increased citations

- maximum visibility for your research: over $100 \mathrm{M}$ website views per year

At BMC, research is always in progress.

Learn more biomedcentral.com/submissions 